\title{
Does corporate social responsibility affect Generation Z purchase intention in the food industry
}

\author{
Man Chung WONG ${ }^{1}$
}

Received: 9 October 2021 / Accepted: 9 October 2021 /Published online: 5 November 2021

(c) The Author(s) 2021, corrected publication 2021

\begin{abstract}
Corporate social responsibility (CSR) becomes more and more prevalent in the business world and is considered as one of the factors to make purchase intentions by customers. Thus, corporations are obliged to implement CSR initiatives to attract their customers. Generation $\mathrm{Z}$ is born in the world with the internet and social media. They are more able to handle technology and reply on the internet or social media to receive or search for information. They are more concerned with social issues or environmental problems. Therefore, CSR is one of the considerations when they make purchase decisions. This study is to explore whether CSR affects Generation $\mathrm{Z}$ purchase intentions in the food industry and which CSR categories have impacts on the purchase intention of Generation Z. A survey was used to collect the data from the youngsters at a post-secondary education institution. The findings showed that Generation $\mathrm{Z}$ will consider the CSR performance of the corporations in the food industry when they made purchase decisions. Most of the CSR initiatives, except shareholder related initiatives, had impacts on purchase intention. This may be due to the characteristics of Generation $\mathrm{Z}$.
\end{abstract}

Keywords Generation Z · Corporate social responsibility (CSR) · Purchase intentions

\section{Introduction}

There were various discussions and arguments among academic researchers and business practitioners about corporate social responsibility (CSR) in these few decades which would be able to influence business practices and consumers' purchase intention or not. CSR is considered a trend in the current business world and also a "must-have" policy among the corporations in Hong Kong. The Hong Kong

Man Chung WONG

albertwong@ln.edu.hk

1 Department of Marketing and International Business, Lingnan University, Hong Kong, Hong Kong 
Business Sustainability Index 2018 showed that there was a substantial improvement in CSR activities among the corporations in Hong Kong during the period between 2016 and 2018, which increased from 45.73 to 50.82 (Hong Kong Polytechnic University, 2018). It indicated that more and more Hong Kong corporations emphasized CSR activities in their strategy and implemented CSR activities in various areas because this would affect the purchase intention of customers.

In the previous studies (Bianchi et al., 2019; Maignan \& Ferrell, 2004; Marin \& Ruiz, 2007), customers' purchase intention would be affected by the CSR initiatives of the corporations but the impacts on customers' purchase intention would be varied among those initiatives. Thus, it is essential for the corporations to review their CSR initiatives and their impacts such that they could justify their investments in CSR. CSR is now a trend and draws more concern and attention from the youngsters who would take the performance of CSR into consideration when they made the purchase decisions.

Moreover, business practitioners and corporations were well noted that various generations had different characteristics and perceptions of ethics and social responsibility (Young \& Nagapal, 2013). The business and marketing practitioners had a key need to understand the characteristics of different generations, as this would affect the approach and strategy in promotion and advertisements based on the target customers of their products and services.

The purchasing power of Generation $\mathrm{Z}$ is now growing and increasing as they have been joining the job market in these few years, so they could have more and more money to spend. As a result, marketers and business practitioners had to consider their thoughts and requirements when they designed their marketing plan and CSR initiatives.

This paper aims at exploring the ethical values and CSR perception of Generation $\mathrm{Z}$ in Hong Kong and whether CSR initiatives by the corporations in the food industry would affect their purchase intention.

\section{Definition of CSR}

CSR was widely elaborated and debated among businesspeople, the public, and academics in the past few decades. Many corporations have included CSR in their business strategy and developed different CSR initiatives for their stakeholders (Hur et al., 2014; Pearce \& Doh, 2005). There were various definitions of CSR, but no single and consensus definition of CSR which could cover all natures related to CSR and the initiatives of CSR implemented in the industry.

The definition of CSR was examined and developed in previous years. Many scholars suggested that CSR should be beyond economic and legal obligations such that the corporations must consider the impacts of their activities on society and community (Asaf et al., 2012; Bowen, 1953; Lantos, 2001). Even though there were some alternative views from other scholars (Friedman, 1970), this explanation and description of CSR were generally accepted by business practitioners and academics. 
There was a growing movement for CSR in the business world and more and more stakeholders requested the corporations to implement CSR initiatives and to pay more concern to the environment and underprivileged people. In addition, the authorized regulators may face difficulty to monitor the behaviors of local corporations in foreign countries, so CSR would be an appropriate and desirable way for the public and stakeholders to review and control the behaviors of the corporations (Scherer \& Palazzo, 2011). Besides, the stakeholders of the corporations would also be concerned with the behaviors of the corporations around the world, not only focus their behaviors in their home country. As a result, CSR became a "must-have" element in business strategy and planning.

\section{Classifications of CSR}

Carroll (1991) considered that CSR initiatives could be assorted into four levels: economic, legal, ethical, and philanthropic which could help to indicate various levels of impacts on stakeholders. This could help the corporations to understand the impacts of their CSR initiatives and the corporations could also collect the opinions and evaluation of various stakeholders on their CSR initiatives.

Besides, Freeman (1984) proposed that corporations must consider the interests of all stakeholders when they made decisions and prepared their strategies. Clarkson (1995) integrated Stakeholder Theory with CSR and suggested that corporations had to consider the stakeholders who had direct interaction with the corporations when they designed their policies. Thus, the categories of stakeholders could be one of the major methodologies to classify CSR initiatives which could help to evaluate the effectiveness of CSR initiatives.

CSR initiatives could be categorized into six types, namely consumers, employees, overseas community, local community, business community, and environment (Brunk, 2010). Other scholars had another view on the classification of CSR initiatives which included customers, environment, suppliers, employees, society, community, and environment (Oberseder et al., 2013). From the viewpoints of business practitioners, they classified CSR initiatives into various categories, for example, community, people (employee), environment, supplier, and voluntary service (CK Hutchison Holdings Limited, 2020; Fairwood Holdings, 2020; Hang Seng Bank, 2020; Maxim's Group, 2020). This paper would adopt the suggestion of Oberseder et al., (2013)because this classification was similar to the practice of corporations in Hong Kong.

The CSR initiatives of each category were discussed and varied among business practitioners and academics. Table 1 provided examples of the CSR initiatives in each category with reference to academics and practitioners suggestions (CK Hutchison Holdings Limited, 2020; Fairwood Holdings, 2020; Hang Seng Bank, 2020; Maxim's Group, 2020; Oberseder et al., 2013).

\section{CSR and customers}

Customers were considered as one of the key stakeholders with a corporation which had an essential influence on the operation and management of a corporation 
Table 1 CSR initiatives in each CSR category

\begin{tabular}{ll}
\hline CSR category & CSR initiatives \\
\hline Community & Voluntary services to community, sponsorship and donations to the community \\
Employee & Work-life balance to the employee, staff development and advancement \\
Shareholder & Company communication with shareholder, risk management of the company \\
Environment & Pollution reduction, sustainability policy with other stakeholders \\
Society & Programme to under-privileged, donation and support to disadvantaged \\
Customer & Accurate information provided to the customer, quality services and fair products \\
Supplier & Supplier management to monitor the quality of supplier, regular review on the \\
& selection of supplier \\
\hline
\end{tabular}

(Buchholtz and Carroll 2012). When the customers found that the corporations could not be trusted due to their unethical behaviors, they might consider not purchasing the products from the corporations (Sen \& Bhattacharya, 2001). Thus, it was very important for corporations to consider the views and opinions of customers when they designed and implemented CSR initiatives.

\section{CSR and food industry}

The corporations in the food industry implemented various CSR initiatives and it showed that these could enhance and had positive impacts on customers' purchase intention (Eastman et al., 2019; Leong \& Mariadass, 2019). In addition, CSR and food safety affected the corporations' reputation and image in the fast-food industry in Hong Kong (Tong et al., 2019). However, there were few studies to examine how CSR initiatives affected the customers' purchase intention in the food industry.

\section{Definition of Generation Z}

There were various definitions to describe and define various generations. Different names and descriptions existed in different literature (Glum, 2015; Howe \& Strauss, 2000; Lancaster \& Stillman, 2002; Martin \& Tulgan, 2002). It was found that there was a disagreement in the characteristics of each generation. However, most scholars considered that Generation $Z$ were the people who were born after 1990.

The period for Generation $\mathrm{Z}$ was also the growth and expansion of personal computers. As a result, Generation $\mathrm{Z}$ would have more opportunities than other generations to receive knowledge of technology when they grew up. One of the key characteristics of Generation $\mathrm{Z}$ was technological savvy and had good handling of social media and digital devices. Generation $\mathrm{Z}$ was born in a small family and normally they received formal education. Thus, they had more general knowledge and got more care from their parents and family.

Generation $\mathrm{Z}$ joined the workplace in these few years, and they could earn more money in the coming few years. As a result, their purchasing power was growing and would affect the business corporations which must take the viewpoints of Generation $\mathrm{Z}$ when they designed their CSR initiatives. 
H1:CSR initiatives have a positive relationship with Generation Z purchase intention in the food industry in Hong Kong.

\section{Generation $\mathrm{Z}$ and CSR}

CSR was common and well accepted in the world. It seemed that young people were more inclined and agreed with the values and practices of CSR. Their purchase intention would be affected by CSR initiatives of the corporations (Leong \& Mariadass, 2019). However, there was little literature to study how CSR affected Generation Z's purchase intention in the food industry in Hong Kong. Thus, this paper is going to fill the gap.

Customers' purchase intention would be reflected by various components including willing to pay more and recommend to others (Creyer, 1997; Zeithaml et al., 1996). Thus, when the corporations implemented CSR initiatives which were aligned and followed with the requirements of the customers, the customers would be willing to pay more and recommend to others.

Customers' purchase intention would be affected by the CSR initiatives of the corporations (Castaldo, et al., 2009; De Pelsmacker et al., 2005). Customers were more willing to purchase the products or services from the corporations which implemented credible and trustful CSR initiatives (Sen \& Bhattacharya, 2001; Yadav \& Pathak, 2017). Thus, some corporations would try to look for endorsements from external public organizations as it could enhance the trustworthiness of the corporations and their CSR initiatives.

CSR initiatives would have positive impacts on customers' purchase intention and corporations' brand (Marin et al., 2009; Sen \& Bhattacharya, 2001). Studies suggested that different initiatives would have varied impacts on customers (Castaldo, et al., 2009; Pomering \& Dolnicar, 2009; Yadav \& Pathak, 2017) and the impacts sometimes could be positive or negative. Some customers would be more interested in specific CSR initiatives, so it was important for the corporations to know and understand the perception of the customers.

The following hypothesis are underdeveloped.

$\mathrm{H} 2 \mathrm{a}$ :Purchase intention of Generation $\mathrm{Z}$ will be positively affected by CSR initiatives (community-related) in the food industry in Hong Kong.

$\mathrm{H} 2 \mathrm{~b}$ :Purchase intention of Generation $\mathrm{Z}$ will be positively affected by CSR initiatives (employee-related) in the food industry in Hong Kong.

$\mathrm{H} 2 \mathrm{c}$ :Purchase intention of Generation $\mathrm{Z}$ will be positively affected by CSR initiatives (shareholder related) in the food industry in Hong Kong.

$\mathrm{H} 2 \mathrm{~d}$ :Purchase intention of Generation $\mathrm{Z}$ will be positively affected by CSR initiatives (environment-related) in the food industry in Hong Kong.

$\mathrm{H} 2 \mathrm{e}$ :Purchase intention of Generation $\mathrm{Z}$ will be positively affected by CSR initiatives (society related) in the food industry in Hong Kong.

H2f:Purchase intention of Generation Z will be positively affected by CSR initiatives (customer-related) in the food industry in Hong Kong. 
$\mathrm{H} 2 \mathrm{~g}$ :Purchase intention of Generation $\mathrm{Z}$ will be positively affected by CSR initiatives (supplier-related) in the food industry in Hong Kong.

\section{Summary}

In summary, CSR played an important role in influencing the purchase intention of customers. In this study, it was to explore the relationship between CSR and purchase intention of Generation $\mathrm{Z}$ in the food industry. The study prescribed the above hypotheses and questionnaire was designed to collect data which could be used to examine the hypothesis.

\section{Methodology}

\section{Sample and procedure}

This study was to examine the relationship between CSR initiatives and purchase intention of Generation Z. The opinions of Generation Z would be collected by a questionnaire and the data from the questionnaire would be analyzed by statistical tests to examine the relationship among those variables. The theoretical framework and hypotheses were developed with reference to the previous literature. Moreover, this study was not going to collect in-depth personal understanding and viewpoints from the respondents. In addition, the questionnaire was designed based on previous studies (Creyer, 1997; Oberseder, et al., 2013; Wong, 2018). The questions were designed in close-ended format because the theories were clear in this study. As a result, a quantitative research approach would be appropriate in this study (Creswell, 2013).

The graduates and students from one medium size tertiary education institution in Hong Kong were contacted to complete the survey. An online questionnaire was set up and the link was distributed to 532 volunteers and 111 completed the questionnaire. Among those completed questionnaires, 102 were usable because 9 of them were born before 1990 which was not the target population. The respondents had their own discretion to answer the questionnaire or not. The information on respondents' identities or responses collected from the questionnaire could not be identified. The questionnaire was designed in bilingual (English and Chinese) so that the respondents could fully understand the questions. Common method bias (CMB) was discussed among researchers and some suggested that CMB might divert the results of the research (Podsakoff et al., 2012; Williams et al., 2010). Some researchers had alternative views which indicated that $\mathrm{CMB}$ was not a crucial factor in the research and it was debateable (Antonakis et al., 2010, 2014; Chang et al., 2010; Spector, 2006). Due to the small scale of the questionnaire in this study and various types of questions were asked in the questionnaire, $\mathrm{CMB}$ would not constitute great impact on the result of the study. 
Table 2 Sample demographic statistics

Table 3 Cronbach's alpha for 4 categories

\section{Measures}

Table 2 showed the demographic characteristics of the respondents. It was noted that the ratio between males and females of the sample was similar to the ratio in Hong Kong (47.81\%:52.19\%) (Census \& Statistics Department, 2019).

\section{Analysis}

The respondents answered 25 questions by using a seven-point Likert scale (ranging from 1 "strongly disagree" to 7 "strongly agree"). Before analyzing the data, Cronbach's alpha was calculated to check the reliability of the data. The 25 questions could be divided into 4 categories. The first 3 questions were used to measure the relationship between CSR and purchase intention in the food industry which could help to test H1. Questions No. 4 to 10 were used to measure the importance of CSR to the respondent. Questions No. 11 to 17 and No. 18 to 24 were used to reflect the purchase intention by using two indicators (willing to pay more and recommend to others). Question No. 25 was to indicate which CSR category respondents had a greater interest and concern. Table 3 showed Cronbach's alpha for 4 categories.

George and Mallery (2003) indicated that the Cronbach's alpha is ranged from 0 to 1 and the closer to 1 , the higher the internal consistency of the data. 0.8 to 0.9 showed excellent internal consistency while 0.7 was at an acceptable level. Thus, the internal consistency was acceptable in the survey as the Cronbach's alpha in different categories were over 0.7 . It showed that the data could be further analyzed as it was reliable.

After considering the reliability of data, the first 3 questions were examined to reflect the relationship between CSR and purchase intention. Table 4 showed the 
mean value and standard deviation of each question and the one-sample $t$-test statistics (significance level $=0.05$ and mean value larger than 5 ).

The mean value of the three questions was statistically significantly greater than 5 which showed that the respondents agreed with the statement in the question. It reflected that the existence of CSR initiatives would affect the purchase decision of the respondents. Respondents were concerned whether the food company had implemented CSR initiatives when they bought their products. Thus, H1 was not rejected by the above analysis. CSR initiatives have a positive relationship with Generation $\mathrm{Z}$ purchase intention in the food industry in Hong Kong.

As shown in Table 5, the mean values of all questions were over 5 which showed that the respondents agreed with the statements in the question. In addition, the $T$-test statistics values of these 7 questions, except Question 6, were greater than the critical value. Thus, the mean value of these 6 questions was statistically greater than 5 which indicated the importance of these 6 CSR categories was significant. However, respondents might not agree with the importance of CSR initiatives related to shareholders.

The purchase intention could be measured by willingness to pay more and recommend to others (Creyer, 1997; Zeithaml et al., 1996) and Tables 6 and 7 showed whether respondents were willing to pay more and recommend to the others when the corporations implemented various CSR initiatives.

With reference to Tables 6 and 7, the mean values of all questions, except Question 13, were over 5. In addition, based on the $T$ Statistic value of the questions, the mean values of all questions, except Question 13 and 20, were statistically significantly greater than 5 . It showed that the respondents were willing to pay more or recommend others when the corporation implemented CSR initiatives, except the initiatives related to shareholders.

\section{Correlation study}

Before analyzing the data by the regression model, the correlation study between the importance of CSR initiatives, willingness to pay more, and recommend others would be conducted and to check whether these 3 factors in the same category would be correlated (Tables 8, 9, 10, 11, 12, 13, and 14).

With reference to the Spearman's correlation coefficient study, it showed that there was a significant correlation among the three variables in each category, as Spearman's correlation coefficients were ranged from 0.538 to 0.757 and $p$-values were 0 . Thus, the regression model could be analyzed in the coming section.

\section{Regression}

As there were two components (willingness to pay more and recommend others) in the dependent variable (purchase intention), a multivariate general linear model would be used to develop a regression model (McCulloch, 2000). There were 7 regression models to indicate how the importance of each CSR category affects purchase intention. The independent variable of the regression model was 


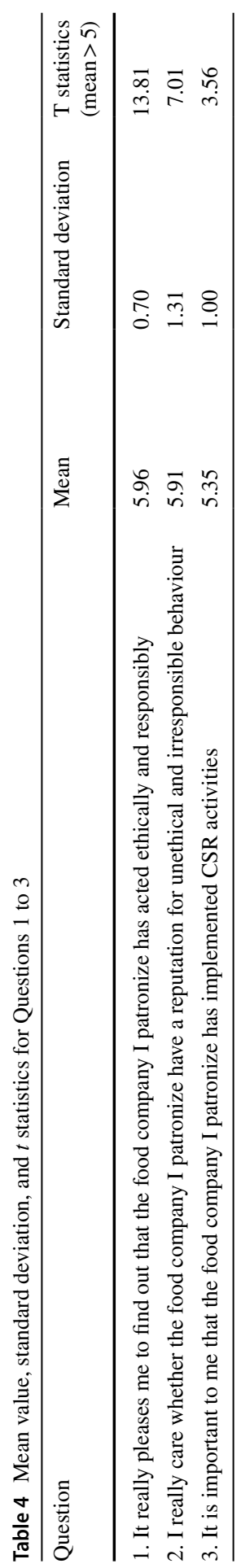




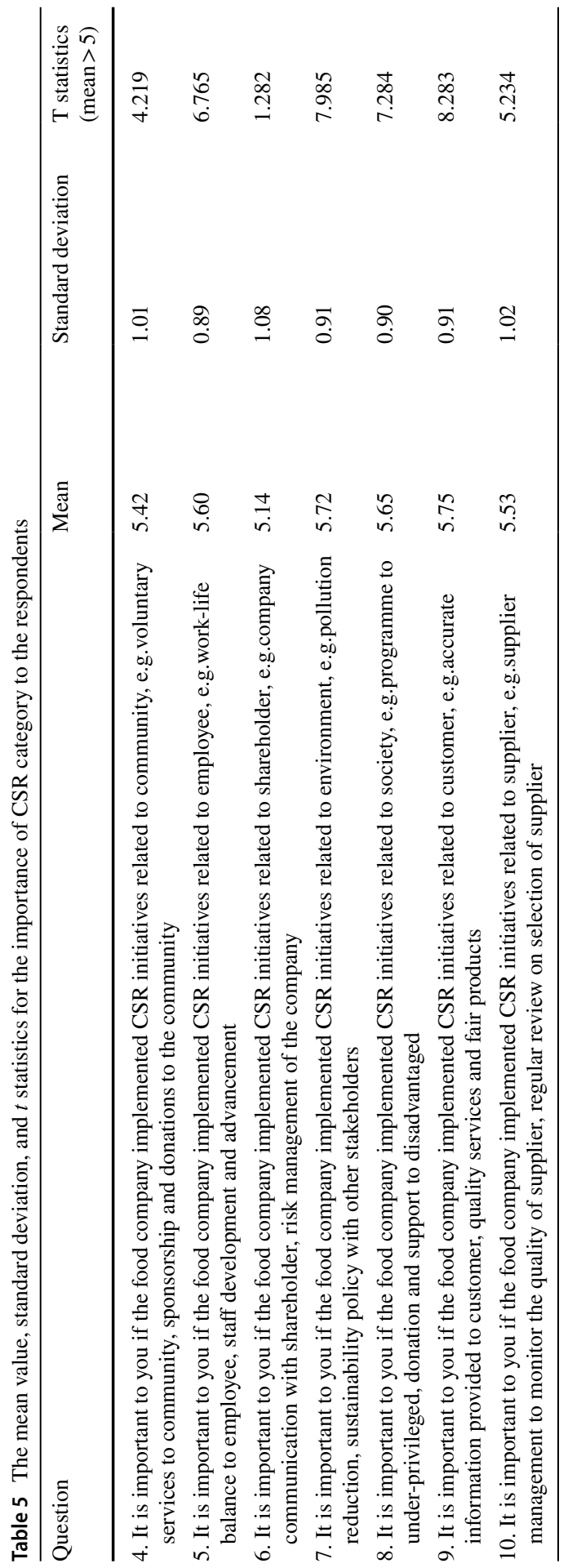




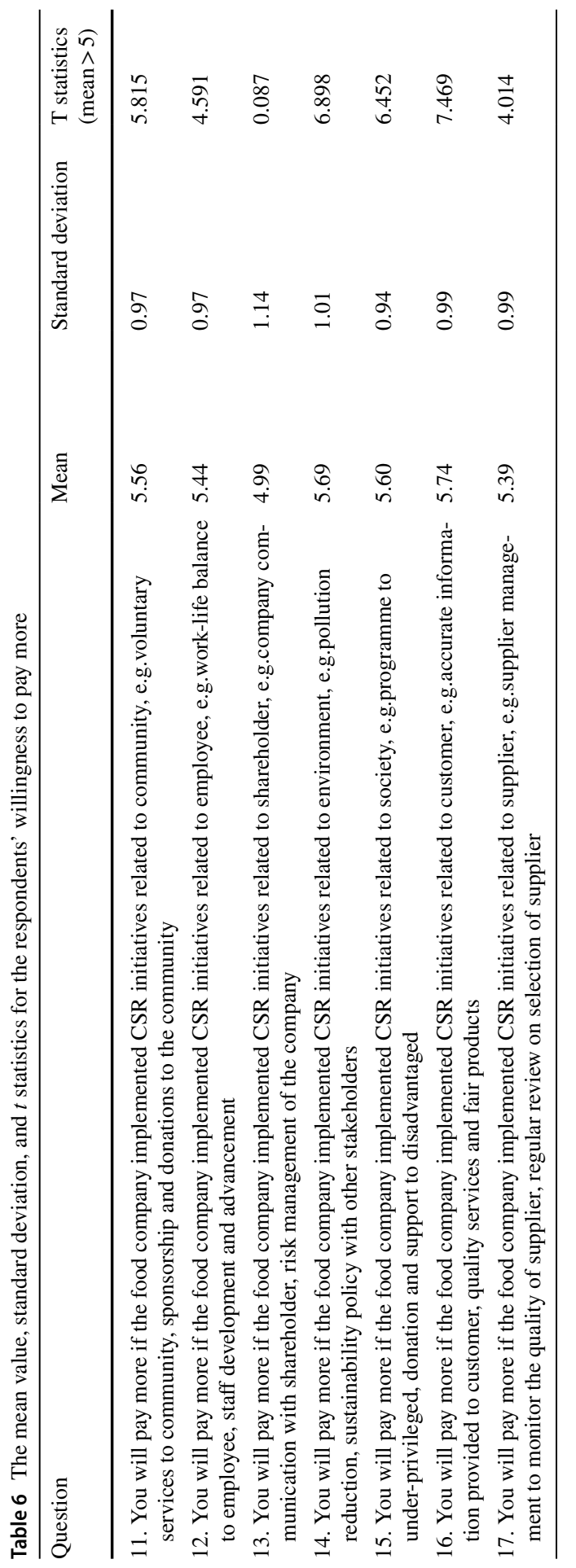




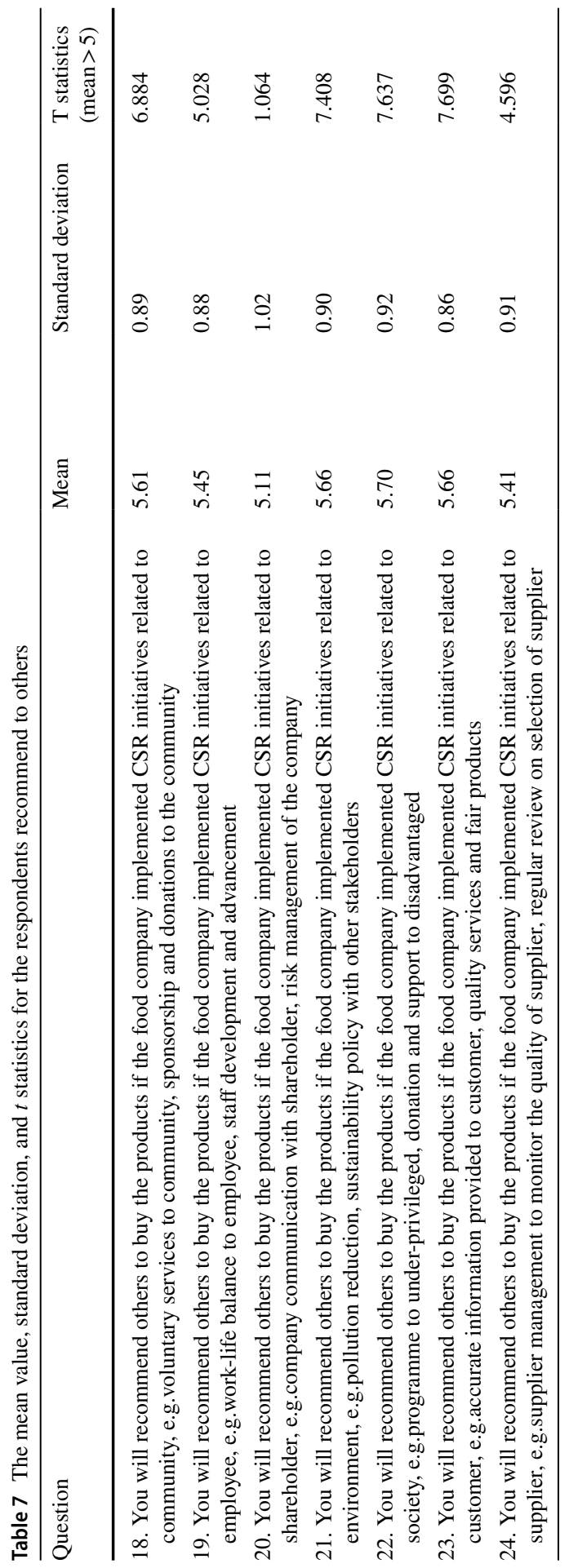


Table 8 Correlation between Q4, 11, and 18 (community category)

Table 9 Correlation between Q5, 12, and 19 (employee category)

Table 10 Correlation between Q6, 13, and 20 (shareholder category)

Table 11 Correlation between Q7, 14, and 21 (environment category)

Table 12 Correlation between Q8, 15, and 22 (society category)

Table 13 Correlation between Q9, 16, and 23 (customer category)

\begin{tabular}{llll}
\hline & Q4 & Q11 & Q18 \\
\hline Q4 & 1 & & \\
Q11 & 0.597 & 1 & \\
Q18 & 0.665 & 0.634 & 1 \\
\hline
\end{tabular}

\begin{tabular}{llll}
\hline & Q5 & Q12 & Q19 \\
\hline Q5 & 1 & & \\
Q12 & 0.671 & 1 & \\
Q19 & 0.578 & 0.674 & 1 \\
\hline
\end{tabular}

\begin{tabular}{llll}
\hline & Q6 & Q13 & Q20 \\
\hline Q6 & 1 & & \\
Q13 & 0.677 & 1 & \\
Q20 & 0.701 & 0.748 & 1 \\
\hline
\end{tabular}

\begin{tabular}{llll}
\hline & Q7 & Q14 & Q21 \\
\hline Q7 & 1 & & \\
Q14 & 0.688 & 1 & \\
Q21 & 0.615 & 0.737 & 1 \\
\hline
\end{tabular}

\begin{tabular}{llll}
\hline & Q8 & Q15 & Q22 \\
\hline Q8 & 1 & & \\
Q15 & 0.635 & 1 & \\
Q22 & 0.680 & 0.704 & 1 \\
\hline
\end{tabular}

\begin{tabular}{llll}
\hline & Q9 & Q16 & Q23 \\
\hline Q9 & 1 & & \\
Q16 & 0.617 & 1 & \\
Q23 & 0.631 & 0.757 & 1 \\
\hline
\end{tabular}


Table 14 Correlation between Q10, 17, and 24 (supplier category)

\begin{tabular}{llll}
\hline & Q10 & Q17 & Q24 \\
\hline Q10 & 1 & & \\
Q17 & 0.674 & 1 & \\
Q24 & 0.538 & 0.652 & 1 \\
\hline
\end{tabular}

the importance of the CSR category which was the mean value (Questions 4 to 10) and the dependent variable of the regression model was purchase intention which was represented by the mean value (Questions 11 to 17 and Questions 18 to 24). Table 15 showed the intercept, coefficient, and significance of the model in different categories.

Based on the result in Table 15, the importance of these 7 CSR categories had impacts on the purchase intention, as the values of $\mathrm{F}$ statistics were greater than critical values.

\section{Summary}

Based on the result of the regression model and one-sample $t$-test, it was found that the 7 CSR categories had positive impacts on purchase intention, except the shareholder category. The mean value of importance and purchase intention was not statistically significantly larger than 5 , such that it implied that respondents did not fully agree that CSR initiatives related to the shareholder category would affect their purchase intention. Therefore, the hypotheses from $\mathrm{H} 2 \mathrm{a}$ to $\mathrm{H} 2 \mathrm{~g}$, except $\mathrm{H} 2 \mathrm{c}$, were not rejected.

\section{Discussion and limitation}

With reference to the analysis result in the previous section, it was found that CSR initiatives had a positive relationship with purchase intention of Generation $\mathrm{Z}$ in Hong Kong which aligned with the previous studies (Sen \& Bhattacharya, 2001; Yadav \& Pathak, 2017) that CSR initiatives were important in the decision of customers.

Table 15 Intercept, coefficient, and F-statistics of the regression model

\begin{tabular}{lccc}
\hline Category & Intercept & Coefficient & F-statistics \\
\hline Community & 0.702 & 2.905 & 53.237 \\
Employee & -1.176 & 3.872 & 85.062 \\
Shareholder & -0.931 & 3.672 & 112.417 \\
Environment & -1.421 & 4.109 & 90.941 \\
Society & -0.463 & 3.529 & 67.633 \\
Customer & -0.957 & 3.858 & 75.902 \\
Supplier & -0.254 & 3.337 & 78.801 \\
\hline
\end{tabular}


In addition, the CSR initiatives related to the shareholder were less concerned by the respondents. Generation $\mathrm{Z}$ just entered the job market, and they might not have much investment in the market. As a result, the CSR initiatives related to the shareholders might not get their attention. They might care more about society and the disadvantaged people.

\section{Limitation}

As this was a cross-sectional study, the findings might only indicate the respondents' behavior at a specific time. The perception of Generation $\mathrm{Z}$ might change due to the occurrence of various issues. A similar study might be conducted later to reflect the latest perception of Generation $\mathrm{Z}$ related to CSR.

In addition, the study focused on the Generation $\mathrm{Z}$ and food industry in Hong Kong. Thus, the result might not be able to extend to other countries or other industries. Different countries or industries might need to conduct a similar study to reflect the perception of their customers.

\section{Conclusion}

The results of this study were consistent with similar research which indicated that CSR initiatives had positive impacts on the purchase intention of the customers. The findings in this study had potential contributions to literature and management. Firstly, the purchasing power of Generation $\mathrm{Z}$ is growing in the next few decades and they were more willing to spend on consumption. Thus, the corporations could try to attract their attention and purchase intention which could enhance the profitability of the corporations. Secondly, the corporations could design their CSR initiatives based on the findings which could enhance the effectiveness of CSR initiatives. This would eventually ensure the investment of CSR initiatives. Finally, the findings of the study could fill the gap of the literature and business practitioners and academics could design the research in similar or related fields or industries based on the findings and design of the study.

Open Access This article is licensed under a Creative Commons Attribution 4.0 International License, which permits use, sharing, adaptation, distribution and reproduction in any medium or format, as long as you give appropriate credit to the original author(s) and the source, provide a link to the Creative Commons licence, and indicate if changes were made. The images or other third party material in this article are included in the article's Creative Commons licence, unless indicated otherwise in a credit line to the material. If material is not included in the article's Creative Commons licence and your intended use is not permitted by statutory regulation or exceeds the permitted use, you will need to obtain permission directly from the copyright holder. To view a copy of this licence, visit http://creativecommons.org/licen ses/by/4.0/. 


\section{References}

Antonakis, J., Bendahan, S., \& Jacquart, P. (2010). On making causal claims: A review and recommendations. The Leadership Quarterly, 21(6), 1086-1120.

Antonakis, J., Bendahan, S., \& Jacquart, P. (2014). Causality and endogeneity: Problems and solutions. In D. V. Day (Ed.), The Oxford Handbook of Leadership and Organizations (pp. 93-117). Oxford Library of Psychology.

Asaf, A. G., Josiassen, A., \& Cvelbar, L. K. (2012). Does triple bottom line reporting improve hotel performance? International Journal of Hospitality Management., 31(1), 596-600.

Bianchi, E., Bruno, J. M., \& Sarabia-Sanchez, F. J. (2019). The impact of perceived CSR on corporate reputation and purchase intention. European Journal of Management and Business Economics, 28(3), 206-221.

Bowen, H. R. (1953). Social Responsibilities of the businessmen. Harper \& Row.

Brunk, K. H. (2010). Exploring origins of ethical company/brand perceptions - A consumer perspective of corporate ethics. Journal of Business Research, 63(3), 255-262.

Buchholtz, A.K. \& Carroll, A.B. (2012). Business \& Society: Ethics \& Stakeholder Management $8^{\text {th }}$ Edition, Canada: South-Western.

Carroll, A. B. (1991). The pyramid of corporate social responsibility: Toward the moral management of organizational stakeholders. Business Horizons, 34(4), 39-48.

Castaldo, S., Perrini, F., Misani, N., \& Tencati, A. (2009). The missing link between corporate social responsibility and consumer trust: The case of fair trade products. Journal of Business Ethics, 84(1), $1-15$.

Census and Statistics Department (2019). Women and men in Hong Kong - Key Statistics (2019 Edition), Retrieved from https://gia.info.gov.hk/general/201907/26/P2019072600332_315537_1_15641 12569814.pdf on 24 Jun 2020.

Chang, S. J., van Witteloostuijn, A., \& Eden, L. (2010). From the editors: Common method variance in international business research. Journal of International Business Studies, 41(1), 178-184.

CK Hutchison Holdings Limited (2020). Environmental, Social and Governance, Retrieved from https:// www.ckh.com.hk/en/esg/ on 23 Jun 2020.

Clarkson, M.B.E. (1995). A stakeholder framework for analyzing and evaluating corporate social performance, the Academy of Management Review, 20(1), pp92-117.

Creswell, J. W. (2013). Research design: Quantitative, qualitative and mixed methods approaches. Sage.

Creyer, E. H. (1997). The influence of firm behavior on purchase intention: Do consumers really care about business ethics? Journal of Consumer Marketing, 14(6), 421-432.

De Pelsmacker, P., Driesen, L., \& Rayp, G. (2005). Do consumers care about ethics? Willingness to Pay for Fair-Trade Coffee, the Journal of Consumer Affairs, 39(2), 363-385.

Eastman, J. K., Smalley, K. B., \& Warren, J. C. (2019). The impact of cause-related marketing on millennials' product attitudes and purchase intention. Journal of Promotion Management, 25(6), 799-826.

Fairwood Holdings (2020). Community, Retrieved from http://www.fairwoodholdings.com.hk/eng/about/ csr_activities.jsp on 23 Jun 2020.

Freeman, R. E. (1984). Strategic management: A stakeholder approach. Pitman/Ballinger.

Friedman, M. (1970). The social responsibility of business is to increase its profits, New York Times Magazine, 13 September.

George, D., \& Mallery, P. (2003). SPSS for Windows step by step: A simple guide and reference. Allyn \& Bacon.

Glum, J. (2015). Marketing to Generation Z: Millennials move aside as brands shift focus to under-18 customers, International Business Time, Retrieved from https://www.ibtimes.com/marketing-gener ation-z-millennials-move-aside-brands-shift-focus-under-18-customers-1782220 on 23 Jun 2020.

Hang Seng Bank (2020). Environment, Social and Governance, Retrieved from https://www.hangseng. com/en-hk/about-us/corporate-sustainability/ on 23 Jun 2020.

Hong Kong Polytechnic University (2018). Announcement of Third Hong Kong Business Sustainability Index Results, Retrieved from https://www.polyu.edu.hk/mm/hkbsi/files/announcement_20180518. pdf on 05 Jun 2020.

Howe, N., \& Strauss, W. (2000). Millennials rising: The next great generation. Vintage Books.

Hur, W., Kim, H., \& Woo, J. (2014). How CSR leads to corporate brand equity: Mediating mechanisms of corporate brand credibility and reputation. Journal of Business Ethics, 125(1), 75-86. 
Lancaster, L.C. \& Stillman, D. (2002). When generations collide. Who they are. Why They Clash. How to solve the generational puzzle at work. New York: Collins Business.

Lantos, G. P. (2001). The boundaries of strategic corporate social responsibility. Journal of Consumer Marketing, 18(2), 595-630.

Leong, T. P., \& Mariadass, A. M. (2019). Factors affecting young adults' purchase intention of green food products in Malaysia. Journal of Tourism, Hospitality \& Culinary Art, 11(2), 20-45.

Maignan, I., \& Ferrell, O. C. (2004). Corporate social responsibility and marketing: An integrative framework. Journal of the Academy of Marketing Science, 32(1), 3-19.

Marin, L., \& Ruiz, S. (2007). 'I need you too!' Corporate identity attractiveness for consumers and the role of social responsibility. Journal of Business Ethics, 71(3), 245-260.

Marin, L., Ruiz, S., \& Rubio, A. (2009). The role of identity salience in the effects of corporate social responsibility on consumer behavior. Journal of Business Ethics, 84(1), 65-78.

Martin, C. A., \& Tulgan, B. (2002). Managing the Generational Mix. HRD Press.

Maxim's Group (2020). Corporate Social Responsibility, Retrieved from https://www.maxims.com.hk/ en/about/cat_01_d.asp on 23 Jun 2020.

McCulloch, C. E. (2000). Generalized linear models. Journal of the American Statistical Association, 95(452), 1320-1324.

Oberseder, M., Schlegelmilch, B. B., \& Murphy, P. E. (2013). CSR practices and consumer perceptions. Journal of Business Research, 66(10), 1839-1851.

Pearce, J. A., \& Doh, J. P. (2005). The high impact of collaborative social initiatives. Sloan Management Review, 46(3), 30-39.

Podsakoff, P. M., MacKenzie, S. B., \& Podsakoff, N. P. (2012). Sources of method bias in social science research and recommendations on how to control it. Annual Review of Psychology, 63(1), 539-569.

Pomering, A., \& Dolnicar, S. (2009). Assessing the prerequisite of successful CSR implementation: Are consumers aware of CSR initiatives? Journal of Business Ethics, 85(2), 285-301.

Scherer, A. G., \& Palazzo, G. (2011). The new political role of business in a globalized world: A review of a new perspective on CSR and its implications for the firm, governance, and democracy. Journal of Management Studies, 48(4), 899-931.

Sen, S., \& Bhattacharya, C. B. (2001). Does doing good always lead to doing better? Consumer reactions to corporate social responsibility. Journal of Marketing Research, 38(2), 225-243.

Spector, P. E. (2006). Method variance in organizational research: Truth or urban legend? Organizational Research Methods, 9(2), 221-232.

Tong, C., Wong, A. T. T., \& Cheng, T. (2019). Do corporate social responsibility and safety of food affect reputation? A Study of Fast-Food Restaurants Industry in Hong Kong, Journal of Economics, Management and Trade, 22(3), 1-18.

Williams, L. J., Hartman, N., \& Cavazotte, F. (2010). Method variance and marker variables: A review and comprehensive CFA marker technique. Organizational Research Methods, 13(3), 477-514.

Wong, M.C. (2018). The impact of corporate social responsibility initiatives of retail banks in Hong Kong on customers' selection of banking services, (Doctoral Dissertation, University of Newcastle).

Yadav, R., \& Pathak, G. S. (2017). Determinants of consumers green purchase behaviour in a developing nation: Applying and extending the theory of planned behaviour. Ecological Economics, 134(1), $114-122$.

Zeithaml, V. A., Berry, L. L., \& Parasuraman, A. (1996). The behavioural consequences of service quality. Journal of Marketing, 60(2), 31-46.

Publisher's note Springer Nature remains neutral with regard to jurisdictional claims in published maps and institutional affiliations. 